\title{
A case of acute lymphoblastic leukemia with additional chromosomes $X$ and 5 associated with a Philadelphia chromosome in the bone marrow
}

\author{
Kemik iliğinde ekstra kromozom 5 ve X'e ilave Philadelphia \\ kromozomu içeren akut lenfoblastik lösemi olgusu
}

\author{
Burak Durmazㄹ, Asude Alpman Durmaz¹, Emin Karaca1, Güray Saydam², \\ Özgür Çoğulu1, Ferda Özkınay \\ 1Department of Medical Genetics, Ege University Faculty of Medicine, Izmir, Turkey \\ 2Department of Internal Medicine, Ege University, Faculty of Medicine, Izmir, Turkey
}

\begin{abstract}
A bstract
We report herein a very rare case of acute lymphoblastic leukemia having a chromosomal constitution of $48, X Y,+X,+5, t(9 ; 22)(q 34 ; q 11)$ in the bone marrow. A patient with additional chromosomes $X$ and 5 with a Philadelphia chromosome has not been reported previously. H owever, no abnormal karyotype was obtained from the lymphocytes in our patient, and he did not have the characteristics of Klinefelter syndrome. He achieved a complete remission with IDA-FLAG and dasatinib therapy. The mechanism of trisomy 5 or any other chromosomal aneuploidy in the pathogenesis of leukemogenesis remains unclear. Further studies involving the genes affected by this karyotype and their products may lead to strategies to further increase the understanding of drug-resistant acute lymphoblastic leukemia and may represent the next frontier in the targeted therapy of those patients. (Turk J Hematol 2010; 27: 299-302)
\end{abstract}

Key words: ALL, X chromosome, chromosome 5, Philadelphia chromosome

Received: December 24, 2009

Accepted: April 30, 2010

Ö zet

Bu makalede, kemik iliğinde çok nadir bir kromozom yapısı olan $48, X Y,+X,+5, t(9 ; 22)(q 34 ; q 11)$ 'e sahip bir olgu sunulmaktadır. E kstra kromozom 5 ve X'e ilave olarak Philadelphia kromozomunu taşıyan bir olguya literatürde rastlanmamıştır. H astamızın lenfositlerden elde edilen karyotipi normal olarak değerlendirilmiş olup, Klinefelter Sendromu kliniği bulunmamaktaydı. IDA-FL AG tedavisi sonucunda tam remisyon sağland.. Trizomi 5 veya diğer kromozomal anöploidilerin lökomogenez üzerindeki rolü net değildir. Karyotipte saptanmıs olan bölgelerdeki genler ve ürünlerinin yapılacak çalışmalarla incelenmesi, ilaca dirençli akut lenfoblastik lösemiyi anlamamızda ve bu hastaların hedefe özgǘn tedavi seçeneklerinde yardımcı olabilecektir. (Turk J Hematol 2010; 27: 299-302)

A nahtar kelimeler: ALL, X kromozomu, kromozom 5, Philadelphia kromozomu

Geliş tarihi: 24 Aralık 2009

Kabul tarihi: 30 Nisan 2010

Address for Correspondence: M.D. Burak Durmaz, Ege University Faculty of Medicine, Department of Medical Genetics, 35100 Bornova, Izmir, Turkey Phone: +90 2323903961 E-mail: burak.durmaz@ege.edu.tr 


\section{Introduction}

Chromosomal abnormalities have been reported in $60-85 \%$ of patients with acute lymphoblastic leukemia (ALL) [1]. Cytogenetic aberrations are not only important in the evaluation of prognosis but are also useful in classifying patients into risk groups [2]. Numerical chromosomal changes such as hypodiploidy are associated with poor outcome, while hyperdiploidy is shown to be associated with a better prognosis [3]. Even though aneuploidies usually occur in autosomal chromosomes, sex chromosome aneuploidies may also be associated with hyperdiploidy in ALL. Trisomy 5 and sex chromosome aneuploidies in high-hyperdiploid karyotypes have been found in $20 \%$ of ALL patients, which revealed poor prognosis [4]. Compared with all chromosomal abnormalities, less is known about patients with trisomies as a sole numerical chromosomal abnormality. Since single trisomies are extremely rare, with an incidence of $1 \%$, their prognostic value and relevant clinical features have not been established in ALL patients [5]. Trisomy 5 is a very rare chromosomal abnormality, with only few cases in the literature, and it is shown to be associated with other chromosomal abnormalities [6]. For instance, an additional $\mathrm{X}$ chromosome is a rare finding observed in the hematological malignancies [7]. Besides numerical abnormalities, Philadelphia (Ph) chromosome is the most common cytogenetic abnormality, occurring in almost $25 \%$ of ALL adults [8]. Here, we present an unusual ALL case with a full karyotype showing an additional $X$ chromosome, chromosome 5 and a $\mathrm{Ph}$ chromosome in the bone marrow, and we discuss the outcomes and the management of these rare chromosomal abnormalities.

\section{Case Report}

An 18-year-old male patient was referred to our hospital with fatigue, weakness and weight loss. On physical examination, massive splenomegaly was recorded (total vertical length: $180 \mathrm{~mm}$ ). The complete blood count (CBC) showed white blood cell (WBC) count 30000/L, hemoglobin ( $\mathrm{Hb}) 10 \mathrm{~g} / \mathrm{dl}$, hematocrit (Hct) 30\%, and platelet (PLT) count $23000 / \mathrm{mm}^{3}$. Peripheral blood smear (PS) showed leukocytosis and the presence of $90 \%$ myeloblastic cells, which were peroxidase- and periodic acidSchiff-(PAS)-negative. Biochemical parameters were within normal limits except lactate dehydrogenase (LDH) of $788 \mathrm{U} / \mathrm{L}$. Bone marrow aspiration and biopsy specimen were consistent with the diagnosis of B-cell ALL showing $90 \%$ myeloblastic cells infiltration. Hoelzer protocol phase I treatment was started [9]. At diagnosis, the karyotype obtained from the bone marrow revealed trisomies of chromosomes $X$ and 5 with a Ph chromosome and was reported as $48, X Y,+X,+5, t(9 ; 22)(q 34 ; q 11)$ (Figure 1 ). In the meantime, molecular BCR/ABL fusion gene was detected by molecular analysis. Regarding the Ph positivity, 400 mg/day imatinib-mesylate combination was added to his chemotherapy regimen. After continuing the treatment for three months, he was hospitalized due to deterioration in his condition and bone pain. Bone marrow aspiration showed more than $90 \%$ peroxidase- and PAS-negative blastic infiltration. Since a very high level of BCR/ABL fusion gene expression was detected by reverse transcription-polymerase chain reaction (RT-PCR), he was considered to be relapsed $\mathrm{Ph}(+) \mathrm{ALL}$, and IDA-FLAG protocol (idarubicin $12 \mathrm{mg} / \mathrm{m}^{2} /$ day 3 days, fludarabine $30 \mathrm{mg} / \mathrm{m}^{2} /$ day 5 days, AraC $2 \mathrm{~g} / \mathrm{m}^{2}$ 5 days) was started. At the time of relapse, cytogenetic analysis from his bone marrow aspiration material showed a full karyotype of $48, X Y,+X,+5, t(9 ; 22)$ (q34; q11), the same as at the time of diagnosis. However, physical examination was not consistent with the features of Klinefelter syndrome, and the cytogenetic evaluation of his peripheral blood showed a normal karyotype. Failure to achieve complete remission led us to add another tyrosine kinase inhibitor, dasatinib $(70$ mg/ day), to the treatment protocol. After one month of the treatment, his bone marrow aspiration showed $4 \%$ blastic infiltration with normal immunohistochemical staining and flow cytometry. During follow-up, cytogenetic analysis of bone marrow aspiration material revealed a normal karyotype, indicating a complete cytogenetic remission. He was considered to be in remission, and he is still under IDA-FLAG and dasatinib treatment. Written informed consent was obtained from the patient's family.

\section{Discussion}

Trisomy 5 usually occurs in a high-hyperdiploid karyotype or secondary to structural abnormalities, in particular $\mathrm{t}(9 ; 22)$ (q34; q11.2), $\mathrm{t}(12 ; 21)$ (p13;q22) and $t(1 ; 19)(q 23 ; p 13)$. Those conditions are more 


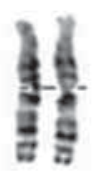

1

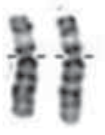

6

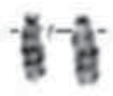

13

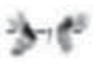

19

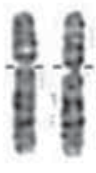

2

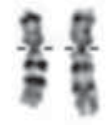

7

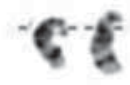

14

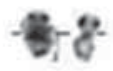

20

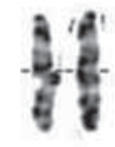

3
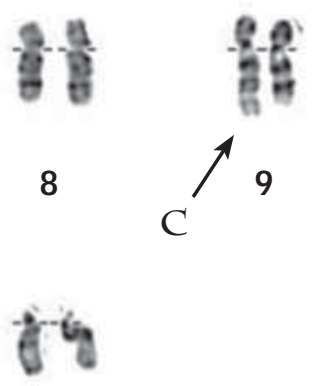

15

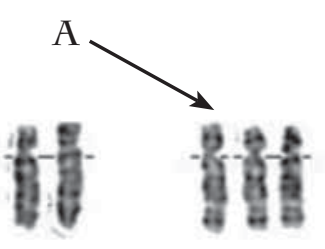

4

5
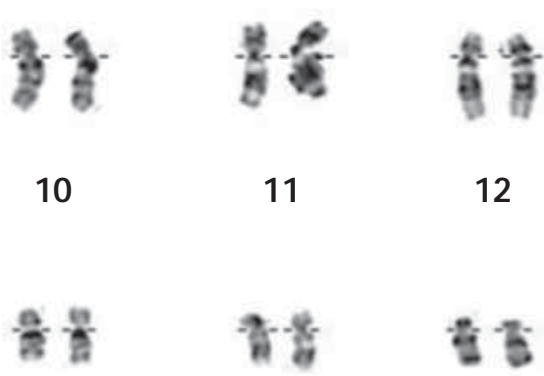

11

12

16

17

18

Figure 1. The karyotype of the patient obtained from bone marrow, showing trisomy $5(\mathrm{~A})$, an extra chromosome $\mathrm{X}(\mathrm{B})$ and the Philadelphia chromosome (C)

frequent than the existence of sole or primary chromosomal abnormality [7]. The mechanism of trisomy 5, or any other chromosomal aneuploidy, in the pathogenesis of leukemogenesis remains unclear. Simple gene-dosage effect and the duplication of a mutation are considered to be two possible results of the gain of a whole chromosome [6]. It has been previously reported that dasatinib, multi-targeted tyrosine kinase inhibitor of BCR-ABL and SRC family kinases, plays an important role in the effective treatment of imatinib-resistant or intolerant Ph-positive ALL patients [10]. In our patient, dasatinib treatment resulted in complete remission. After treatment, bone marrow aspiration biopsy showed normal immunohistochemical staining, flow cytometry and cytogenetic results. Although the influence of additional aberrations on the result of the treatment with tyrosine kinase inhibitors in Ph-positive ALL requires large patient series, we think that our patient demonstrates a pioneer achievement during the course of ALL management.
Genes affected by chromosomal alterations tend to be involved in the pathways that control cell growth or development. Functional studies of these gene products may reveal the complex mechanisms playing a role in the pathogenesis of leukemogenesis and may help in the design of new therapeutic strategies.

\section{Conflict of Interest}

No author of this paper has a conflict of interest, including specific financial interests, relationships, and/or affiliations relevant to the subject matter or materials included in this manuscript.

\section{References}

1. Secker-Walker LM, Prentice HG, Durrant J, Richards S, Hall E, Harrison G. Cytogenetics adds independent prognostic information in adults with acute lymphoblastic leukaemia on MRC trial UKALL XA. MRC Adult Leukaemia Working Party. Br J Haematol 1997;96: 601-10 
2. Faderl S, Kantarjian HM, Talpaz M, Estrov Z. Clinical significance of cytogenetic abnormalities in adult acute Iymphoblastic leukemia. Blood 1998;91:39954019.

3. Heerema NA, Nachman JB, Sather HN, Sensel MG, Lee MK, Hutchinson R, Lange BJ , Steinherz PG, Bostrom B, Gaynon PS, Uckun F. Hypodiploidy with less than 45 chromosomes confers adverse risk in childhood acute Iymphoblastic leukemia: a report from the Children's Cancer Group. Blood 1999;94:4036-45.

4. Heerema NA, Sather $H N$, Sensel MG, Zhang $T$, Hutchinson RJ , Nachman JB, Lange BJ , Steinherz PG, Bostrom BC, Reaman GH, Gaynon PS, Uckun FM. Prognostic impact of trisomies of chromosomes 10, 17 and 5 among children with acute lymphoblastic leukemia and high hyperdiploidy (>50 chromosomes). J Clin Oncol 2000;18:1876-87.

5. Guptaa, V, Chunb K. Trisomy 4 as the sole cytogenetic abnormality in a patient with T-cell acute lymphoblastic leukemia. Cancer Genet Cytogenet 2004;152:158-62.

6. Haris RL, Harrison CJ , Martineau M, Taylor KE, Moorman AV. Is trisomy 5 a distinct cytogenetic subgroup in acute
Iymphoblastic leukemia? Cancer Genet Cytogenet 2004;148:159-62.

7. Mitelman F, J ohansson B, Mertens F. Mitelman Database of Chromosome Aberrations in Cancer. 2/2003 update. Available at: http://cgap.nci.nih.gov/Chromosomes/ Mitelman Accessed December 21, 2009.

8. Radich JP. Philadelphia chromosome-positive acute Iymphocytic leukemia. Hematol Oncol Clin North Am 2001;15:21-36.

9. Hoelzer $D$, Thiel $E$, Löffler $H$, Bodenstein $H$, Plaumann $L$, Büchner T, Urbanitz D, Koch P, Heimpel H, Engelhardt R. Recruiting patients and results of a preliminary study on the therapy of acute lymphatic leukemia and acute undifferentiated leukemia in adults. Onkologie 1983;6:170-4.

10. Ottmann O, Dombret H, Martinelli G, Simonsson B, Guilhot F, Larson RA, Rege-Cambrin G, Radich J, Hochhaus A, Apanovitch AM, Gollerkeri A, Coutre S. Dasatinib induces rapid hematologic and cytogenetic responses in adult patients with Philadelphia chromosome-positive acute lymphoblastic leukemia with resistance or intolerance to imatinib: interim results of a Phase II study. Blood 2007;110:2309-15. 